\title{
The concept of triple Helix extended model in Lodz in the light of own work
}

Ph.D. Justyna Trippner-Hrabi Academy of Social Science Faculty of Management, Chair of Management, Lodz

\section{Introduction}

The cooperation of science and business environment and public sector contributing to implementation of innovative solutions that constitute the main determinant of knowledge-based economy, becomes more and more meaningful.

In 1995 Henry Etzkowitz and LoetLeydesdorff came up with triple Helix model which was originally created for biological and medical purposes. Its main task is to define dynamics of correlations between three major institutional spheres of this model (Etzkowitz, Leydesdorff 1995 pp.14-19). Among these entities there are higher education facilities, enterprises and authorities governing in the given region (Maciejczak, Muniak 2007, p.4). Thus, triple Helix defines various behaviours and connections between different entities which create some networks within knowledgebased organizations. The significance of business-science-administration relationship is raised in many public debates or conferences which tend to combine science and business environment in order to initiate mutual knowledge transfer, which simultaneously ought to be supported 
by local authorities. Eliminating any hardship or increasing opportunities within the model should lead to creating conditions propitious for innovative solutions development in knowledge-based economy.

The aim of the paper is to examine the functioning of the triple Helix extended model in Lodz and to describe the barriers inhibiting the cooperation between parties.

\section{Description of triple Helix extended model}

The object of interest in the article being experimental substance and the starting point for further analytical penetration was global enterprises located in Lodz. In comparison with other model participants they have the biggest material and non-material potential facilitating modern organizational changes including innovative ones. Thanks to innovativeness, the above mentioned alterations may be placed on the first position in triple Helix model, at the same time becoming its active constituent. In these type of enterprises much more work is done by international teams often exceeding the traditionally established competence limits. Therefore, the role of above mentioned teams is rapidly growing in local and international organizations which are modernly managed (M. Brzeziński 2009, p. 73). In the surveys apart from higher education schools (like in H. Etzkowitz and L. Leydesdorff's model) scientific entities were also taken into consideration because they are to a large extent knowledge depositaries and have big potential for innovative solutions. Another assumption is the fact that except for administrative institutions other entities or projects aimed at regional knowledge transfer were regarded as well. They are independent organizations separated from administrative structures, institutions cooperating with them and other entities aiming to accelerate relationship between business and science in the region. Triple Helix extended model was presented in figure 1.

It is essential that the policy of cooperation between these entities should be steered so as to initiate demand for goods among consumers and not to limit oneself to supply management of already existing knowledge solutions (Camison, Devece, Garrigos, Palacios 2008, p. 12). Clashes may arise in these partnerships due to such groups not undergoing the characteristic creation phases. According to B. Tuckman, when shaping teams, there are four classic phases: formation, clash, stabilization and action (Clayton M., 2009, p. 32).This cycle is typical of static groups and is one of their proper developmental determinants, and also has a positive impact on goal achievement. 


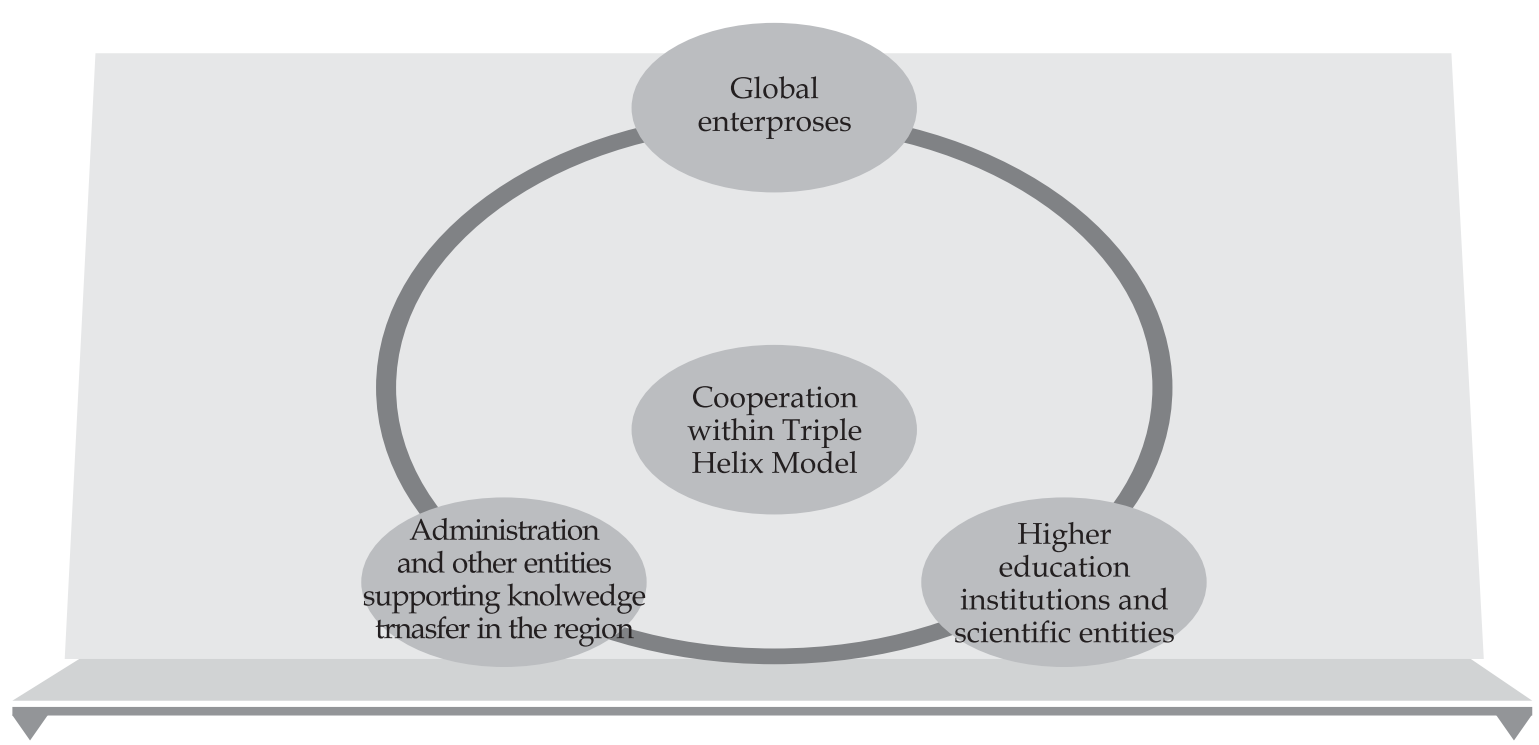

Figure 1. Triple Helix extended model

Source: own work

\section{Sampling plan}

Qualitative and quantitative survey comprises purposive sample including entities within triple Helix extended model in Lodz in the years 2004-2012. It means that these surveys are not representative. Purposive sampling was determined by the choice of research units being the object of analysis, taking into account the criteria established. It resulted from a limited number of entities involved in triple Helix extended model operating in the city of Lodz. It is worth mentioning that at the same time each organization was conducting multithreaded surveys applying diversified techniques, which reflected the overall image of the given entities' operation. The sample was also constructed on the basis of data availability. The surveyed organizations were divided into three parts: global enterprises, $Ł M Z W^{1}$, Lodz administrative institutions

1 LMZW - Lodz international knowledge teams. Groups consisting of at least two people differing from each other in terms of origin or/and culture or/and nationality. They are international teams basing on the possessed knowledge that focus on reaching common goals or creating solutions that can be applied by various business entities afterwards. Their members can work remotely or portably. Decision and coordination center is situated in Lodz knowledge organizations. People who create such unions are 
and other bodies called on the city's initiative. Each group received a different questionnaire. The questions asked during a free or expert interview were different as well. On the one hand the problem of the interview embraced the specificity of the given organization, but on the other hand its representatives answered uniformly formulated questions. The issues raised in the polls also aimed at reconnoitering opinions on the functioning of triple Helix entities from the surveyed units' perspective.

Twenty-five out of thirty institutions agreed to be subjected to the survey. Out of this group twenty-one entities revealed some data. Nine units refused to participate in the poll. Some of the global enterprises were not willing to disclose their strategies e.g. in the scope of investment intentions, connections with other organizations, underlying that gathering information is too time-consuming and emphasizing that confidential information is not allowed. Table 1 depicts the structure of the surveyed organizations. Global enterprises were representing (among others) by: Gillettte, Sonoco, Indesit. ŁMZW were representing (among others) by: Technical University of Lodz, Academy of Social Science, Polish Academy of Science. Local executive powers were representing (among others) by Polish Agency for Regional Development, Marshall office, Town Hall.

Table 1. Number and profile of surveyed entities

\begin{tabular}{l|c|c}
\hline $\begin{array}{c}\text { Organization's business activity } \\
\text { profile }\end{array}$ & $\begin{array}{c}\text { Number of organizations } \\
\text { by business activity profile }\end{array}$ & $\begin{array}{c}\text { Percentage share in the } \\
\text { total number of surveyed } \\
\text { entities }\end{array}$ \\
\hline EMZW & 7 & 33.33 \\
\hline Global enterprises & 7 & 33.33 \\
\hline Local executive powers & 7 & 33.33 \\
\hline In total & 21 & $\mathbf{1 0 0}$ \\
\hline
\end{tabular}

Source: own work

mostly representatives of science but they can also represent business environment or local authorities. Therefore, these teams are mainly hybrid in terms of the number of people involved, their qualifications, or engagement in implementation of particular project stages. 


\section{Relevance of triple Helix extended model constituents in the light of surveys}

Below there are some selected responses from the questionnaire addressed to representatives of global enterprises, ŁMZW and local governments.

In the first question the surveyed could decide if global businesses cooperate with $€ M Z W$. Figure 2 illustrates the percentage of answers.

Vast majority of answers $(71,40 \%)$ speak volumes that global enterprises did not enter into cooperation with $€ M Z W$ in order to transfer knowledge into their structures and resources. For $28,60 \%$ of companies such cooperation has already been brought into existence.

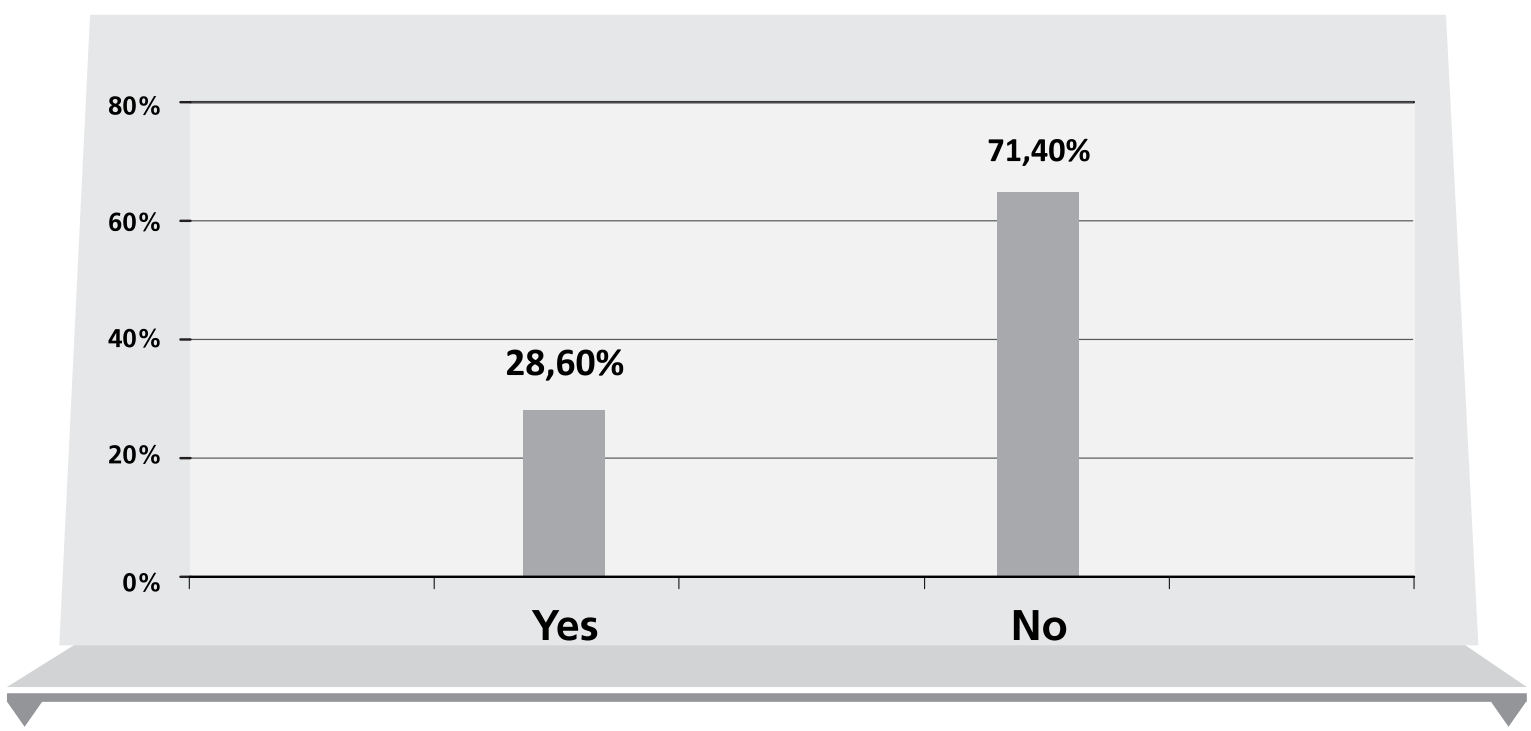

Figure 2. Cooperation of enterprises and $t M Z W$

Source: own work based on the conducted surveys

A supplement of the above answer was the question aimed at identification of reasons for which collaboration between global enterprises operating in Lodz and $Ł M Z W$ is so marginal. Figure 3 presents the percentage of responses.

The same percentage $(28,60 \%)$ is attributed to two responses. The first puts emphasis on the lack of information (LoI) on the business activity and hitherto achievements of ŁMZW. The second answer indicates that administrative obstacles $(\mathrm{AB})$ in the area of Lodz are a very significant factor hampering the cooperation of those entities. For $24 \%$ of the surveyed, organizational barriers 


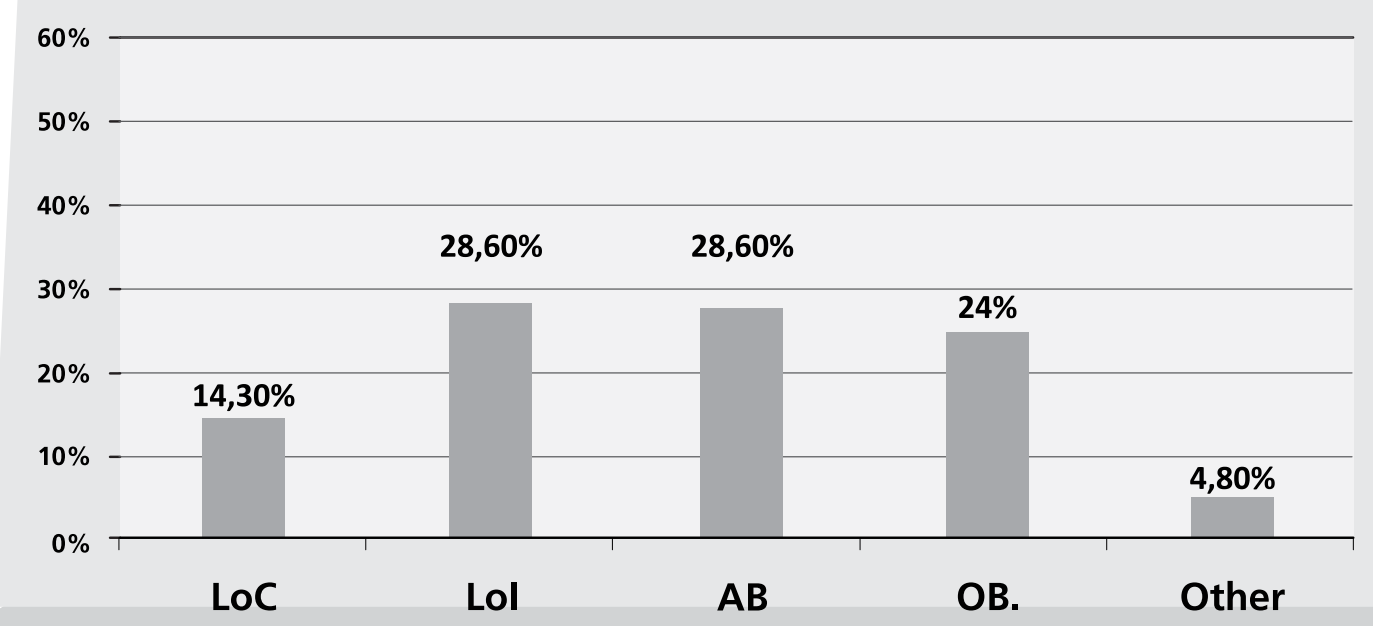

Figure 3. Reasons of lack of cooperation between global enterprises and $k M Z W$ (from the enterprises' point of view)

Source: own work based on the conducted surveys

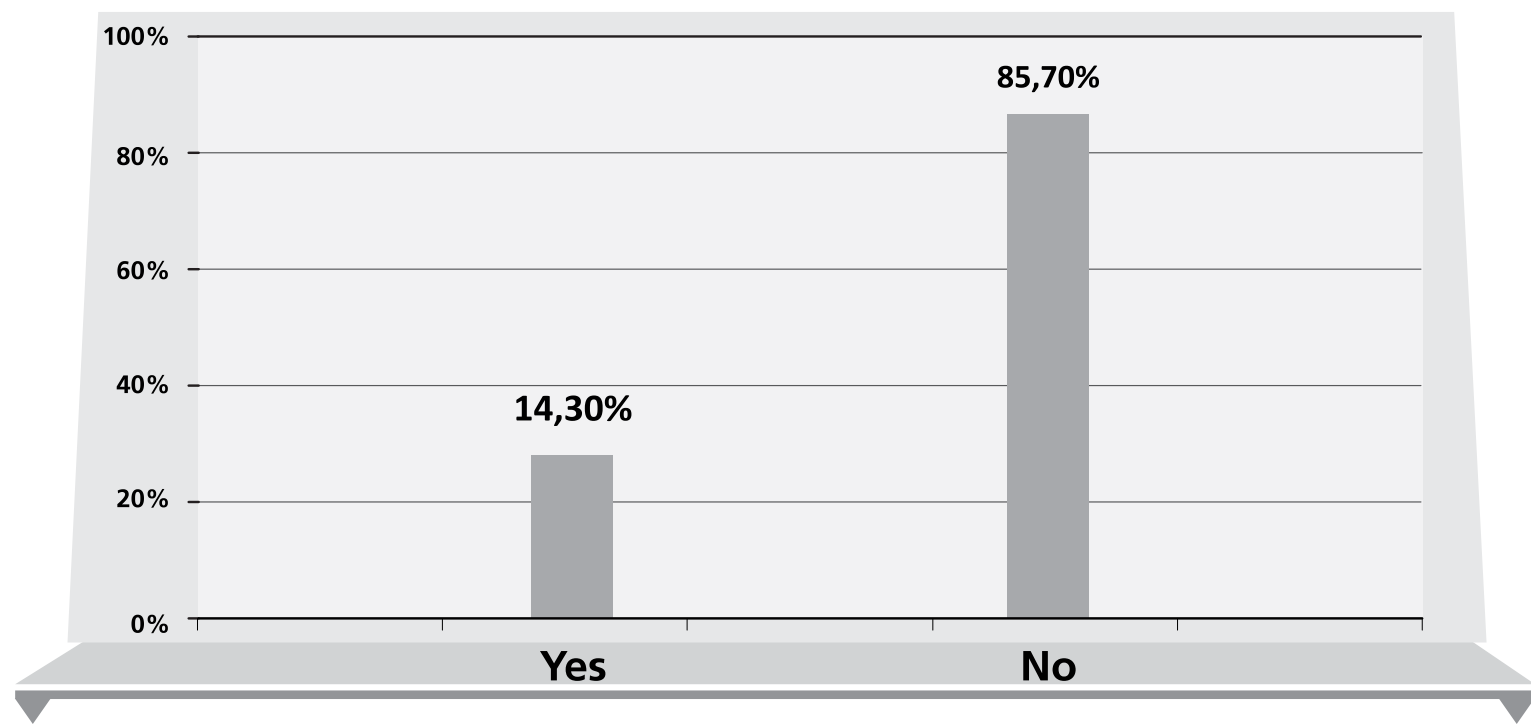

Figure 4. Companies' knowledge on the scope of research or projects implemented by $Ł M Z W$

Source: own work based on the conducted surveys 
$(\mathrm{OB})$ are the main deterrent to initiate the collaboration of this kind. The response indicating the lack of confidence (LoC) towards $Ł M Z W$ was attributed to $14,30 \%$ of interviewed enterprises.

The issue that was respectively raised concerned the companies' knowledge on the areas of research or the projects implemented by ŁMZW. Figure 4 illustrates the percentage figures.

Vast majority of respondents admitted that their knowledge on the issues raised within ŁMZW structures was absolutely marginal. Just $14,30 \%$ of the interviewed were informed about the area and scope of Lodz scientific workers' activity.

In the next question the surveyed were asked to define their intentions and plans affecting their cooperation with ŁMZW. Figure 5 shows all the collected answers.

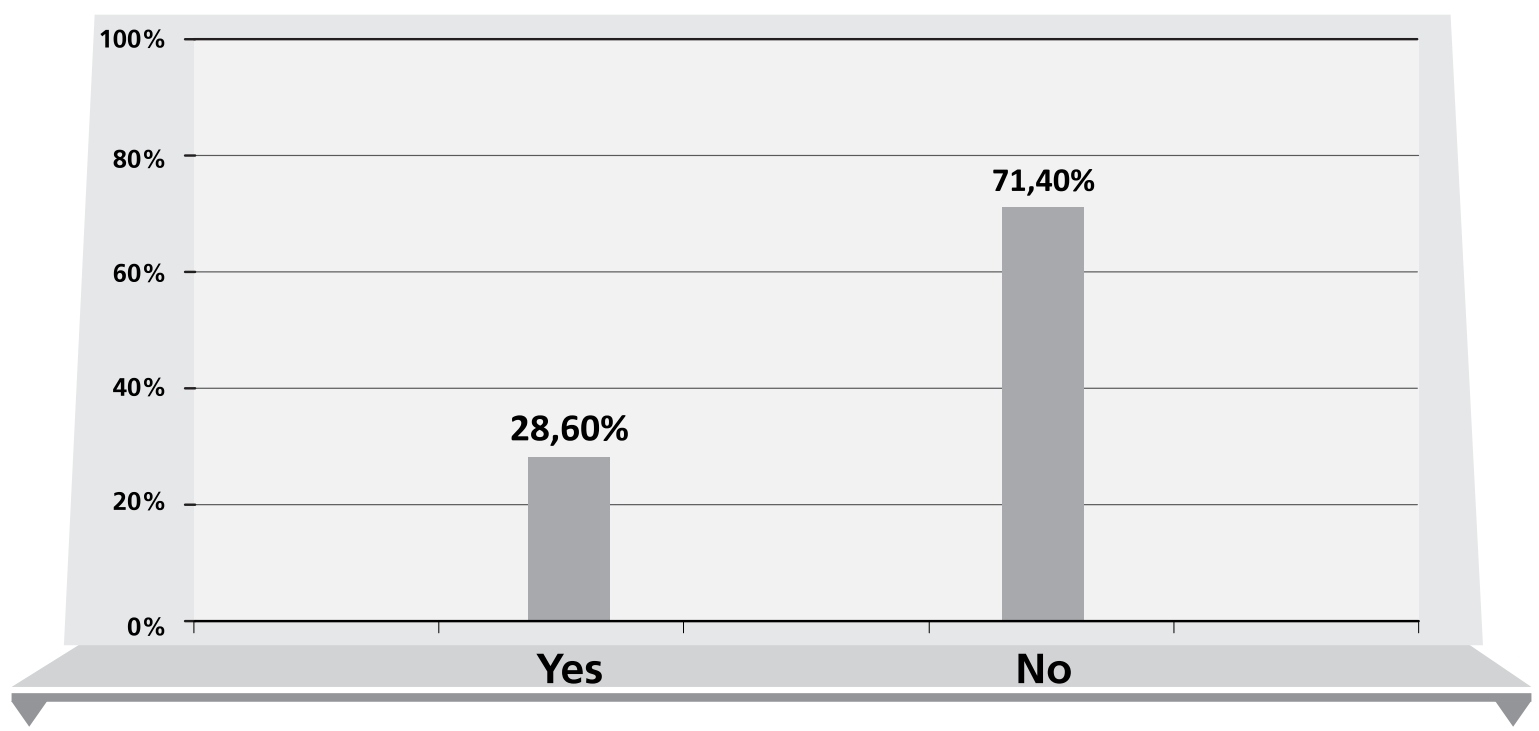

Figure 5. ŁMZW and global enterprises cooperation plan

Source: own work based on the conducted surveys

Vast majority of respondents $(71,40 \%)$ acknowledged that $Ł M Z W$ would not cooperate with global businesses in the nearest future, which means that their plans are not defined for the time being. The teams whose cooperation with the mentioned companies is in progress are going to continue this partnership in the future $(28,60 \%)$.

Figure 6 depicts the reasons of marginal cooperation between global enterprises and ŁMZW. 
$28,60 \%$ of respondents regard lack of companies' demand (LoD) for ŁMZW's services as the most important factor hampering their mutual cooperation. The surveyed also claimed that their insufficient knowledge (LoI) on ŁMZW's scope of activity and hitherto achievements, letting alone marginal and inconspicuous promotion, constitute a meaningful deterrent to cooperation commencement (19,0\% of respondents). $14,30 \%$ of the interviewed consider financial barriers as something that hinders collaboration.

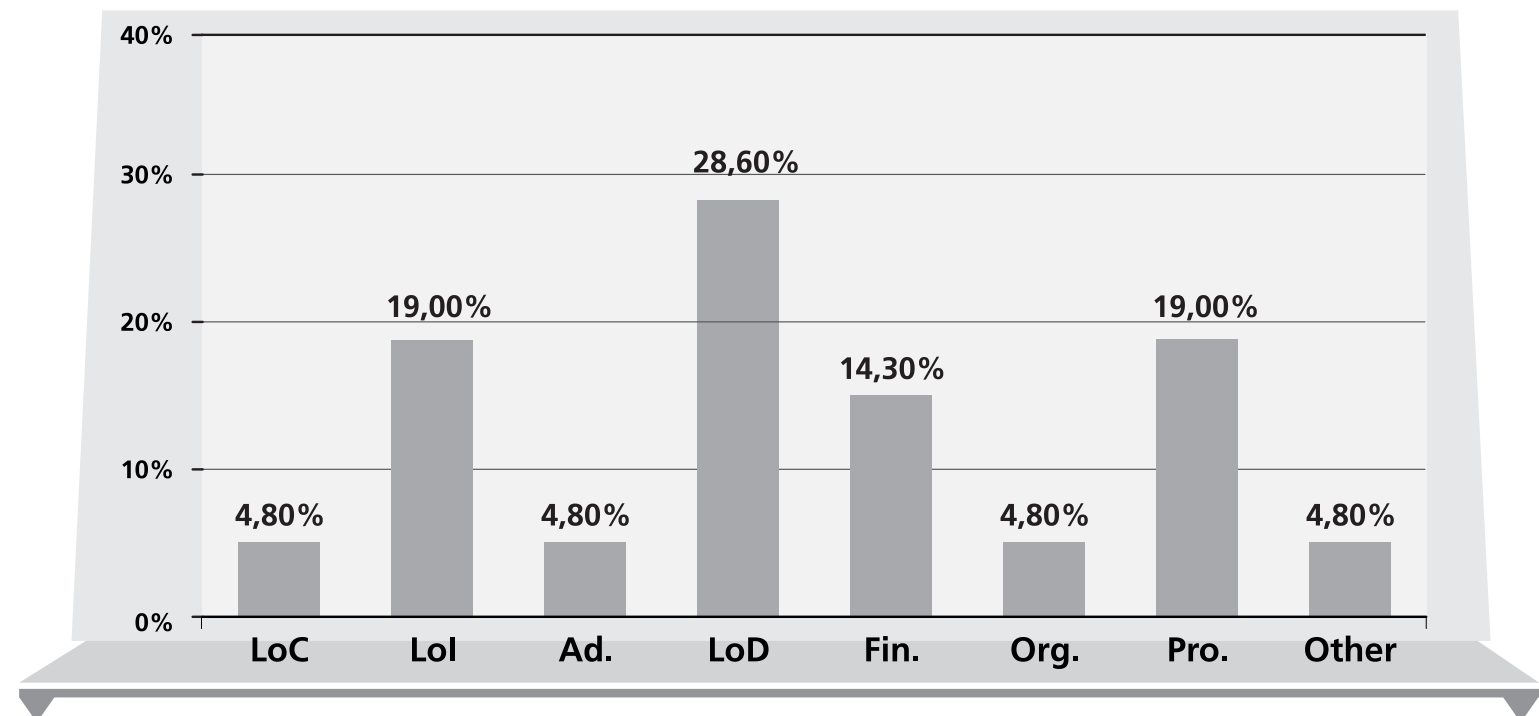

Figure 6. Reasons of lack of cooperation between global enterprises and $Ł M Z W$ (from the $\mathrm{KMZW}$ 's point of view)

Source: own work based on the conducted surveys

Another issue in the poll concerned self-government project initiation aimed at cooperation between ŁMZW and global businesses. Figure 7 presents the percentage of responses.

Nearly three quarters of respondents $(71,40 \%)$ highlight that local government does not make any effort in order to establish cooperation between the above mentioned entities. Slightly over a quarter $(28,60 \%)$ of the surveyed stated that such collaboration had occurred. It mainly referred to participation in fairs, seminars or conferences.

The question concerning obstacles which ŁMZW may encounter while cooperating with global business received the following percentage distribution of responses (figure 8). 


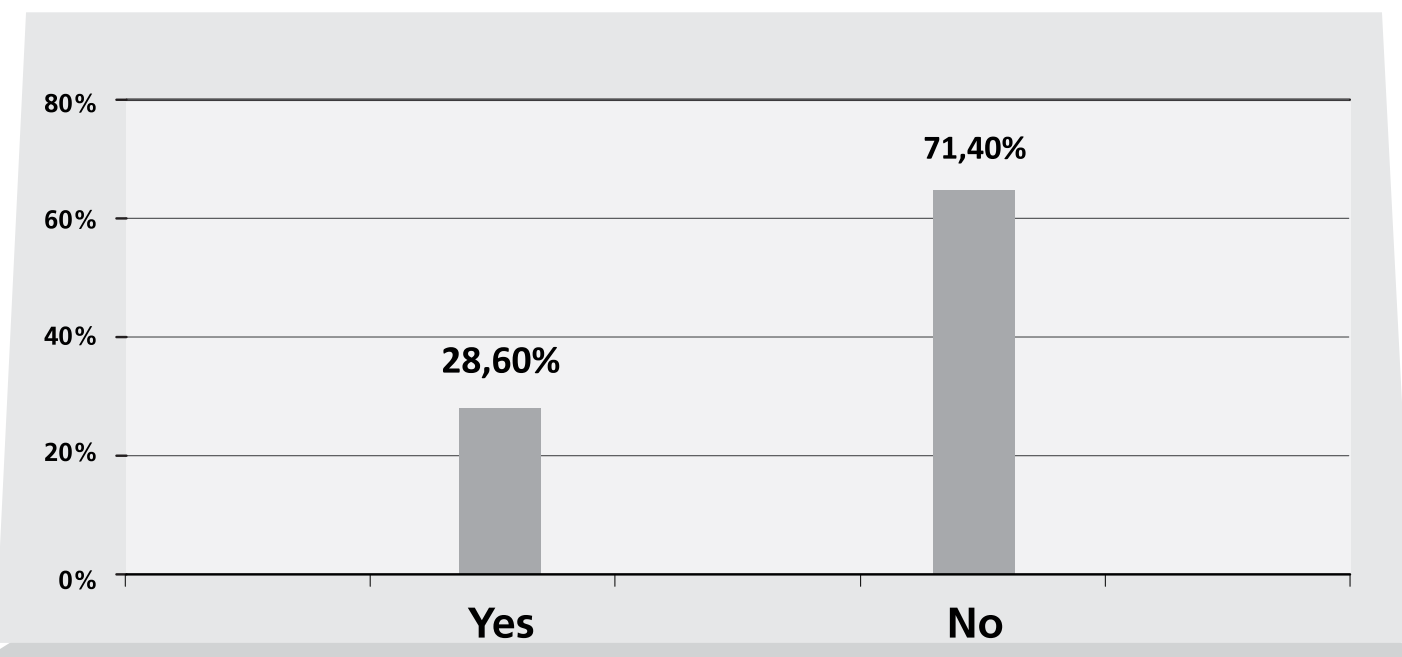

Figure 7. Project initiation for cooperation between $Ł M Z W$ and business Source: own work based on the conducted surveys

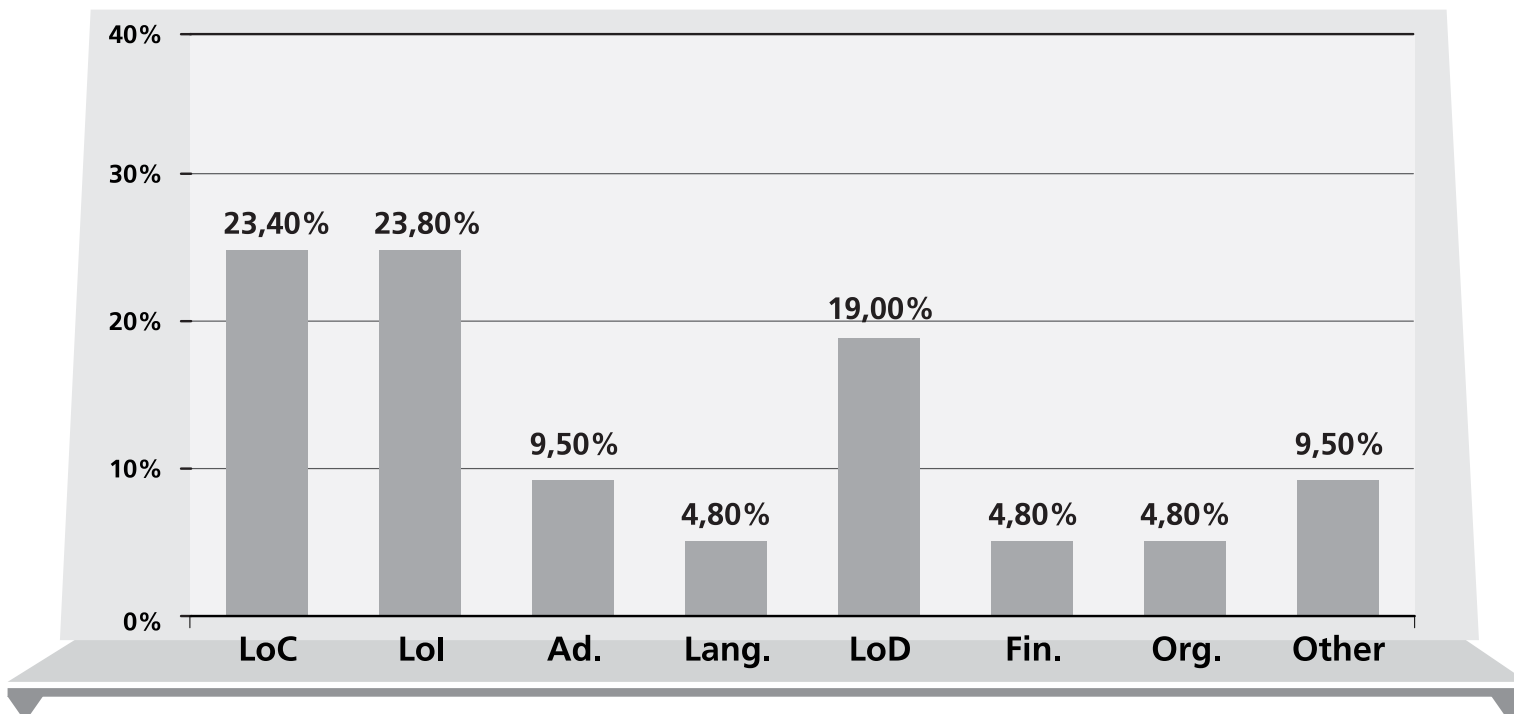

Figure 8. Reasons of lack of cooperation between global enterprises and $k M Z W$ (from local government's point of view)

Source: own work based on the conducted surveys

$23,80 \%$ of respondents indicate that among the most tremendous hindrances there can be listed: lack of companies' confidence in ŁMZW (LoC) and 
insufficient knowledge (LoI) on the scope of its activity and achievements. The questioned also claimed that lack of business demand (LoD) for ŁMZW services is a noticeable deterrent to establishment of cooperation between these parties $(19,0 \%)$. Slightly less than five per cent of the surveyed regard administrative procedures (Ad.) as an obstacle hard to overcome.

\section{Conclusion}

Having analyzed the above-revealed answers one can reach conclusions and put forward some recommendations constituting the article summary.

Lodz local government definitely ought to be more active in terms of business. Taking relationship between business and science into consideration, its current activity comes down to the basic "care" about investors intending to start their undertakings in the territory of Lodz (e.g. providing technical infrastructure, or supporting production labor recruitment). Administration of the city of Lodz should much more often come up with concrete business solutions which global enterprises could apply in their units, together with ŁMZW. This kind of offer could come into being thanks to collaboration of $Ł M Z W$, consulting companies or local governments operating in Polish cities like Wrocław or Gdynia where R\&D units are thriving and resilient.

The role of administration of Lodz frequently ends up with project initiation. Any scope of project implementation and coordination is not established. It means that self-government does not have any possibility to respond to newly arisen problems at the proper time and consecutively apply some solutions for the given problem. Therefore, each investment in Lodz, which involves global enterprises, could have its own "carer" within administrative structures (e.g. in the form of knowledge broker) whose task would be comprehensive investment and post-investment service. The carer would also be a lobbying entity for investment development of production and R\&D fields.

Bureaucracy and administrative hindrances occurring in the executive powers of Lodz result in companies' unwillingness to cooperate with ŁMZW within triple Helix extended model. It expresses itself in project duration, lack of suitable communication or insufficient flexibility for cities to adapt to the individual requirements of $€ M Z W$ or investors.

Administration should be more business-oriented. It also has to perceive its own structures through the prism of a rapid response to the needs of ŁMZW and investors, preceded by identification of needs and supporting resources from EU funds. 
Lobbying of the city of Lodz and extensive promotion of its image as a scientific competence centre in present and future companies are pretty vestigial. Global businesses do not know the subject-matter of work performed by ŁMZW. Enterprises are not aware of the extent to which these works could boost the functioning and development of ŁMZW units.

Bearing this in mind, it would be good to initiate appropriate actions aimed at ŁMZW image promotion with global enterprises. Taking into consideration the fact that vast majority of strategic decisions on the functioning of those companies are made in parent headquarters (that is out of the territory of Lodz), this kind of action should be addressed directly to the headquarters. EMZW can successfully cooperate in the network with other knowledge teams across Poland. As a consequence, it will strengthen their scientific potential, which respectively will lead to increased attractiveness for big overseas investors.

ŁMZW ought to be more active in terms of business. Its activity for science and business relationship most frequently amounts to elaborating on various projects with which they try to arouse potential investors' interest (often ineffectively). It often happens that ŁMZW passively "hopes for" cooperation initiated by the enterprise itself.

ŁMZW should much more often come up with concrete business solutions which global enterprises could apply in their units. This kind of offer could come into being thanks to collaboration of consulting companies or local governments operating in Polish cities like Wrocław or Gdynia where R\&D units are thriving and resilient.

\section{Summary}

The concept of triple Helix extended model in Lodz in the light of own work

The functioning and development of enterprises are determined by transferring up-to-date knowledge into their structures. Therefore, entities being market leaders should enter into cooperation with scientific units which are providers of new solutions as well technical as organizational ones. Such cooperation in the region should be carried out with the participation of local authorities whose job is multi-dimensional and long-term support for the parties involved.

Key words: knowledge management, cooperation, enterprise, knowledge teams. 


\section{Streszczenie}

Koncepcja rozszerzonego modelu potrójnej Heliksy w Lodzi w świetle badań własnych

Funkcjonowanie i rozwój przedsiębiorstw determinowane jest między innymi przez dopływ do ich struktur aktualnej wiedzy. Podmioty będące liderami rynkowymi winny wobec tego wchodzić we współpracę z jednostki naukowymi, które są dostawcami nowoczesnych rozwiązań zarówno technicznych jak i organizacyjnych. Kooperacja taka $w$ danym regionie powinna być przeprowadzana przy udziale organów samorządowych, których zadaniem jest wielopłaszczyznowa i długotrwała pomoc między zainteresowanymi stronami.

\section{Słowa}

kluczowe: $\quad$ zarządzanie wiedza, kooperacja, przedsiębiorstwo, zespoty wiedzy.

\section{References}

1. Brzeziński M., (2009), Organizacja kreatywna, PWN, Warszawa.

2. Camison C., Devece C., Garrigos F., Palacios D. (2008), Connectivity and Knowledge Management in Virtual Organizations: Networking and Developing Interactive Communications, ISF, London.

3. Clyaton M., (2009), Management Models Pocketbook, Management Pocketbooks Ltd, Guilford.

4. Etzkowitz H., Leydesdorff L. (1995), The TripleHelix - University Industry - Government Relations: A Laboratory for Knowledge Based Economic Development, EASTT Review 14.

5. Maciejczak M., Muniak R. (2007), Zastosowanie koncepcji potrójnej heliksy $w$ tworzeniu narzędzi informatycznych dla sektora publicznego, X jubileuszowa konferencja Komputerowo Zintegrowane Zarządzanie, Zakopane. 